\title{
Tanulmányok
}

\section{MONGÓLIA KÜLPOLITIKAI CÉLKITǓZÉSEI ÉS SZEREPE A TÁVOL-KELETI BIZTONSÁGPOLITIKAI KONFLIKTUSOKBAN}

\section{THE FOREIGN POLICY AIMS AND ROLE OF MONGOLIA IN THE SECURITY CONFLICTS OF THE FAR EASTERN REGION}

\author{
Szilágyi Zsolt \\ PhD, tudományos fömunkatárs, MTA Bölcsészettudományi Kutatóközpont Néprajztudományi Intézet \\ szilagyi.zsolt@btk.mta.hu
}

\begin{abstract}
ÖSSZEFOGLALÁS
Mongólia különleges biztonsági helyzetben van: hatalmas területű, ásványkincsekben gazdag, de ritkán lakott és viszonylag fejletlen országként két hatalmas szomszédja között egyensúlyozva kell megőriznie mozgásterét. Különösen a kínai kapcsolatoknál áll fenn annak a veszélye, hogy az ország egyoldalú függésbe kerül. Az ország a "harmadik szomszéd” koncepcióval, kapcsolatai diverzifikálásával, atomfegyvermentes státuszának elismertetésével, továbbá aktív külpolitikával - például az észak-koreai rendezési kísérletekben való szerepvállalással és az ENSZ békefenntartó műveleteiben való részvétellel - igyekszik biztosítani önállóságát. Mindezt úgy, hogy Mongólia a térség egyetlen működő demokráciája. A sajátos pozíció okozta nehézségek ellenére az ország mindeddig sikeresnek mondható fő céljai elérésében.
\end{abstract}

\begin{abstract}
Mongolia is in a very special security situation: a country with a huge territory and a lot of natural resources, but sparsely inhabited and relatively underdeveloped, it must keep its space of movement locked between two giant neighbours. Its relations to China always come with the risk of becoming too reliant on one side. Mongolia strives to maintain its status as an independent actor by its 'third neighbour' concept, the diversification of its relations, its promotion of its nuclear weapon free status, and its active foreign policy, such as taking part in the management of the North Korean crises and in UN peace-keeping operations. All these is done while being the sole functioning democracy in the region. Despite the problems caused by its special position, the country has been quite successful so far in reaching its main aims.
\end{abstract}

Kulcsszavak: Mongólia, harmadik szomszéd politika, atomfegyvermentes státusz

Keywords: Mongolia, third neighbour policy, nuclear weapon free status 
Mongólia az 1989-90-es rendszerváltást megelőző évszázadokban jórészt az országgal szomszédos és egymással rivalizáló nagyhatalmak politikai játékszere volt, de ma már független, koherens külpolitikát folytató ország, amely méretét meghazudtoló mértékben játszik szerepet a térségben.

\section{A FÜGGETLEN MONGÓLIA}

Mongólia számára a szovjet rendszer összeomlását kísérő politikai folyamatok teremtették meg annak lehetőségét, hogy az 1946. január 5-én Kína által is elismert függetlenségét végre valós politikai önállóságra válthassa (Batbayar, 2002, 273.; Szilágyi, 2010a, 261.; Szilágyi, 2010b, 113.). Az 1990-es rendszerváltás teremtette meg a lehetőséget arra is, hogy kiléphessenek a korábbi korszak diplomáciai elszigeteltségéből. Ez a nyitás elsősorban a kínai-mongol kapcsolatok átalakítását jelentette, de hamar egyértelmúvé vált az is, hogy a mindkét szomszédja mellett eltörpülő Mongólia számára elengedhetetlenül fontos a más országokkal való kapcsolatfelvétel is. Az ázsiai gazdasági nagyhatalmak, Japán, Dél-Korea és Kína között verseny alakult ki a mongóliai gazdasági befolyás megszerzéséért, s ez ma az egyre fokozódó kínai gazdasági túlsúly - és az ebből eredő politikai befolyás következtében, ha lehet, még kiélezettebb.

A mongol diplomácia tudatosan próbálja kihasználni ezt a rivalizálást, $\mathrm{s}$ részben erre alapozza az ún. „harmadik szomszéd” politikáját is. A törekvés azt a célt szolgálja, hogy az ország „láthatóvá váljon” a nemzetközi diplomáciai porondon, hiszen - ahogyan azt a 18. és a 20. század közepe között hasonló történeti pályát befutó Tibet példája is mutatja - csak a stabil nemzetközi kapcsolatok biztosíthatják hosszú távon az ország függetlenségét és ellenálló képességét a kínai gazdasági (és politikai) befolyással szemben.

E folyamat első lépéseként 1990 után mindkét szomszéddal új alapokra kellett helyezni a diplomáciai kapcsolatokat. 1991-ben már hivatalos kínai delegáció látogatott Ulánbátorba, majd konfliktusok árán ugyan, de az orosz kormánnyal is sikerült rendezni a kapcsolatokat. 1993-ban megkötötték a két ország közötti új barátsági és együttmüködési szerződést, melyet egy évvel később a hasonló kínai-mongol egyezmény aláírása követett.

Az oroszok 1992-es kivonulását követően a mongol gazdasági helyzet katasztrofálissá vált, ezt csak jelentős külföldi tőkebevonással, segélyekkel lehetett viszonylag rövid idő alatt normalizálni, de az évtized közepén már érezni lehetett, hogy a mongol gazdasági kapcsolatokban Kína fogja átvenni azt a pozíciót, amit a korábbi korszakban a Szovjetunió töltött be (Szilágyi, 2010b, 117.; Szilágyi, 2015, 24-25.). 


\section{A KÍNAI-MONGOL KAPCSOLATOK ÉS A GAZDASÁGI BEFOLYÁS KIÉPÜLÉSE}

Annak ellenére, hogy a mongol rendszerváltás éppen az egypártrendszer felszámolását, a kínaitól részben idegen gazdasági modell kialakítását célozta, 1994-es ulánbátori látogatásán Li Peng kínai államfó aláírta az új kétoldalú egyezményt, melyben Kína elismerte Mongólia függetlenségét, önállóságát, területi integritását, és a kölcsönös előnyökön alapuló kereskedelmi és gazdasági kapcsolatok fejlesztését tüzte ki célul.

A KGST (Kölcsönös Gazdasági Segitség Tanácsa) megszünése és az orosz kivonulás után a mongol gazdaság gyakorlatilag az összeomlás szélére került. A megüresedett pozíciókat azonban Kína könnyedén be tudta tölteni. 1995-ben már Mongólia második legnagyobb kereskedelmi partnere volt, 1999-re pedig a vezető szerepet is megszerezte. 2004-ben a mongol export 48\%-a irányult Kínába, és a külföldi befektetések 38\%-a származott onnan. A gazdasági befolyás kialakításával és az egyre nyomasztóbb gazdasági erőfölénnyel nőtt Kína lehetősége a kétoldalú kapcsolatok irányítására is.

Gazdasági értelemben Mongólia számára ez a kapcsolat áldás és átok is egyben. A kínai gazdaság szinte kielégíthetetlen nyersanyagigénye komoly lehetőségeket rejt a mongol gazdaság számára, hiszen Mongólia igen jelentős készletekkel rendelkezik szénből, rézből, aranyból, illetve más ipari nyersanyagokból. 2003ban első külföldi útján - mely szintén a kiemelt kínai figyelem bizonyítéka - Hu Csin-tao (Hu Jintao) kínai államelnök-pártfőtitkár hivatalosan is megerősítette, hogy Kína érdekelt a mongóliai beruházások fokozásában, a gazdasági kapcsolat megerősítésében (Szilágyi, 2009, 250.).

Egy évvel később a mongol államfő, Natsagiin Bagabandi pekingi viszontlátogatásakor szintén üdvözölte a kínai befektetéseket. A két ország együttmüködésének köszönhetően a 2003-as 23 millió dollárnyi kínai bányászati beruházás egy évvel később már 3,7-szeresére, 86 millió dollárra nőtt, a kínai részesedés a külföldi bányászati beruházások 30\%-a volt (Batchimeg, 2005, 2.). Még 2003-ban egy 300 millió dolláros kedvezményes kölcsönt is kilátásba helyeztek a mongol bányászat mint kiemelten fontos gazdasági tényező fejlesztése érdekében. A 2000-es évek elejétől már minden szempontból Kína vált az első számú partnerré, a tendenciák azonban a gazdasági függés kialakulásának irányába mutattak.

A 2000-es évek vége a mongol gazdaság látványos bővülését hozta. Ebben a kínai befektetéseknek kiemelt szerepük volt, de ez tovább fokozta a gazdaság kínai kitettségét is. 2014-re a teljes mongol külkereskedelem immár több mint kétharmada (67,8\%) kapcsolódott Kínához, és a mongol kivitel 81\%-a irányult a déli szomszéd felé (URL1). Az ilyen mértékű kapcsolat - mongol szemmel nézve inkább kiszolgáltatottság - immár a szovjet befolyás időszakát idézi.

Napjainkban az egymást követő mongol kormányok mindent meg is tesznek annak érdekében, hogy ezt a függést csökkentsék, de ennek ellenére Kína ké- 
pes gazdasági befolyását politikai céljai érdekében latba vetni (Gao, 2017). 2016 novemberében a legmagasabb politikai fórumokon hevesen tiltakozott, amiért Mongólia engedélyezte a dalai láma beutazását, és a látogatás külpolitikai következménye végül az lett, hogy Kína felmondta a Mongóliának szánt 4,2 milliárd dolláros kölcsönt.

\section{A HARMADIK SZOMSZÉD POLITIKA}

A 21. század mongol kormányai jelentős erőfeszítéseket tesznek annak érdekében, hogy megőrizzék a mongol diplomácia mozgásterét, a gazdaság és kereskedelem működtetésének kereteit. Az „üllő és a kalapács” (Ewing, 1980), a két szomszédos nagyhatalom szorításából való kitörés egyik legfontosabb eszköze a mongol kormányzat által már az 1990-es évek legvégén meghirdetett, de lényegében inkább az utóbbi másfél évtizedet jellemző ún. „harmadik szomszéd” politika.

A doktrína azt célozza, hogy Mongólia önálló, független külpolitikát folytatva „láthatóvá váljék” a nemzetközi porondon, hogy jelentős gazdasági, politikai erőt képviselő harmadik országokkal alakítson ki önálló kapcsolatokat.

Az elképzelést először az 1990-ben Mongóliába látogató James Baker amerikai külügyminiszter fogalmazta meg, amikor arra utalt, hogy a mongolok gondoljanak nyugodtan úgy az USA-ra, mint harmadik szomszédjukra. Baker megnyilvánulását nyilvánvalóan retorikai fordulatnak szánta, később azonban egy egész külpolitikai koncepció névadójává vált.

Mongólia függetlenségének biztosítéka, hogy a nemzetközi politikai porond független szereplőjévé kell válnia. A rendszerváltás korai időszakában a belpolitikai struktúrák átalakításával párhuzamosan a legfontosabb feladat a két szomszédos nagyhatalommal való kapcsolat rendezése volt, melyben az USA, az ENSZ és általában a nyugati államok támogatása által biztosított „hátország” komoly szerepet játszott. Ez a kérdés a kétoldalú szerződések megkötésével gyakorlatilag az évtized derekára megoldódott.

A nyugati országokban müködő minták alapján dolgozták ki a mongol választási rendszert, amely a mai félelnöki berendezkedéssel a demokratikus müködés alapját biztosítja. Ezzel Mongólia a posztszovjet térségben egyedülálló kormányzati berendezkedést hozott létre, $s$ ami még fontosabb, sikerült ezt a demokratikus normák alapján müködtetnie is. Az 1990 óta lezajlott parlamenti és elnökválasztások demokratikus voltát nem kérdőjelezte meg a nemzetközi közösség, és nem történtek alkotmánymódosítások sem az elnöki jogkörök kibővítése érdekében.

A harmadik ország politika nemcsak diplomáciai, de gazdasági értelemben is sikeresnek tekinthető. A donor országok által nyújtott anyagi támogatás segített kiépíteni a piagazdaság kereteit, lábra állítani a mongol bankrendszert (Rossabi, 2005, 54.). A bilaterális kapcsolatok kialakítása mellett a mongolok törekedtek a 
multilaterális együttmüködések megerősítésére is. 1997-ben az ország a WTO (World Trade Organization, Kereskedelmi Világszervezet) tagjává vált, 1998ban belépett az ASEAN (Association of Southeast Asian Nations, Délkelet-ázsiai Nemzetek Szövetsége) regionális fórumába, és 2012-ben csatlakozott az Európai Biztonsági és Együttműködési Szervezet munkájához is. Napjainkban Mongólia ötvenkét nemzetközi, regionális vagy világszervezet teljes jogú vagy társult tagja (URL2).

E kapcsolatokban nemcsak az USA, a kelet- és délkelet-ázsiai országok váltak Mongólia fontos partnerévé, de az Európai Unió és azon belül Magyarország is. A mongolok a rendszerváltás első éveitől kezdődően törekedtek arra, hogy a Magyarország és Mongólia között korábban kialakult jó viszonyra alapozzák a két ország kapcsolatát. Már 1992-ben kezdeményezték a nyolc évvel korábban megkötött és hatályban lévő barátsági és együttmüködési szerződés újratárgyalását, amit a magyar kormányok a kölcsönös államföi látogatások ellenére is vonakodtak újrakötni. Ez az álláspont 1996-ban változott meg, s az új szerződést 1998. január 28-án aláírták.

A nemzetközi szerepvállalás fontos területének tekinthető a mongol katonák részvétele a békefenntartó missziókban, melyekben 2003 óta nagyjából 14 ezer mongol tejesített szolgálatot az egész világon. Jellemzően az USA katonai erejével közösen végzik ezt a tevékenységet. Jelenleg a dél-szudáni ENSZ-békefenntartók között szolgálnak mongol katonák (URL3). Mongólia olyan egyedi katonai stratégiát fejlesztett ki, mely megpróbál egyensúlyt teremteni a hagyományos és a békefenntartó képességek között, és ez épp a nemzetközi szerepvállalások miatt fontos pillére a mongol nemzetbiztonsági koncepciónak is.

A mongol nemzetbiztonsági stratégiát 2011-ben publikálták. Ebben deklarálták az emberi jogok védelmét, a szabadság, a jogállamiság és a demokratikus kormányzás biztosítását, de ezek alapfeltételeként a nemzetbiztonságot fogalmazták meg (URL4). A koncepció közreadása összhangba hozható a 2009-ben az államelnöki pozíciót elfoglaló Cahiagín Elbegdordzs (Tsakhiagiin Elbegdorj) külpolitikai elképzeléseivel, melyet a félelnöki kormányzati struktúra által nyújtott lehetőségeket kihasználva a 2010-es évek elejétől markánsan képviselt. Aktív „kisállami politikát” hirdetett, ami a lehető legszélesebb nemzetközi együttmüködés megteremtését célozta.

Mongólia minden diplomáciai vonalon erősítette jelenlétét, legyen szó a regionális szervezetekről, az ázsiai gazdasági nagyhatalmakról vagy éppen az Európai Unióról. Ebben a folyamatban kiemelt fontosságú a biztonságpolitikai együttmüködés, mely elsősorban 2001. szeptember 11. óta a belsö- és kelet-ázsiai térség egyik fontos diplomáciai problémája is. Mongólia délnyugati határa szomszédos a kínai Hszincsianggal (Xinjiang), pontosabban a Hszincsiang-Ujgur Autonóm Területtel, így nem meglepő, hogy a biztonsági kérdések az egyik legfontosabb részét alkotják a két ország kapcsolatának. 
Mongólia ma már éppen stabilitásával járul hozzá a térség biztonságának megőrzéséhez, s ebben tudatos építkezés is megfigyelhető. Rendszeresen tartanak nemzetközi békefenntartó gyakorlatokat, az ország 2005 óta tagja az USA által létrehozott Globális Békefenntartó Kezdeményezésnek (GPOI, Global Peace Operations Initiative), melynek ezek a gyakorlatok fontos elemei. Hasonló céllal valósulnak meg azok a katasztrófaelhárítási gyakorlatok, melyeket Góbi Farkas (halha Gow' Chono) elnevezéssel éves rendszerességgel szerveznek meg Mongóliában. A 2017 évi transz-csendes-óceáni katasztrófavédelmi gyakorlaton a kezdeményezést irányító két ország, Mongólia és az Egyesült Államok mellett jelen voltak Banglades, Kanada, Japán, Nepál, Új-Zéland, Dél-Korea és Magyarország képviselői is. A mongolok diplomáciai egyensúlyra való törekvésének jele, hogy ezeken a gyakorlatokon egyes években Kína képviselöi is megjelennek, és az északi határ mentén orosz-mongol közös gyakorlatot is szerveztek 2015-ben.

Az egyensúly megteremtésére való törekvés jó példája, hogy Mongólia és Oroszország 2009-ben kötött stratégiai partnerségi megállapodást, ezt a mongolkínai relációban 2011-ben követte hasonló szerződés, amelyet 2014-ben átfogó stratégiai partnerségi megállapodás megkötésével bővítettek ki.

\section{A MONGOL ATOMFEGYVERMENTES STÁTUSZ}

A rendszerváltás utáni mongol külpolitikai törekvések emblematikus jelképe az atomfegyvermentes státusz elfogadtatásáért tett erőfeszítés. A mongolok 1992től, az ENSZ-bejelentés után következetesen dolgoztak azon, hogy a nemzetközi közösség elfogadja ezt az egyedülálló módon csupán egy állam által deklarált - ún. Single State NWFS (single-state nuclear-weapon-free-status) - státuszt (Jakab, 2013). A kezdeményezés nagyban hozzájárult a régió biztonságának növekedéséhez, okai pedig azokban a történeti tapasztalatokban gyökereznek, melyek miatt a mongolok gazdasági és politikai értelemben is megpróbálnak egyenlő távolságot tartani mindkét szomszédjuktól.

A rendszerváltást megelőző időszakban, főleg az 1960-as évek második felétől megromló szovjet-kínai viszony következtében a szovjet haderő gyakorlatilag felvonulási területként kezelte Mongóliát. Nagyjából 65-70 ezer szovjet katonát telepítettek a mongol-kínai határ közelébe, s a hadosztályokat közepes hatótávolságú ballisztikus rakétákkal is felszerelték, így Mongólia - önhibáján kívül közvetlen nukleáris csapás célpontjává is válhatott. Ebben a helyzetben az enyhülést csak a szovjet szövetségi rendszer felbomlása hozta.

A fentiek alapján egyértelmü, hogy a mongol politikai függetlenség szempontjából milyen jelentőségủ az atomfegyvermentes státusz 1992-ben történt bejelentése. A nemzetközi közösség és a Mongóliával szorosabb diplomáciai kapcso- 
latban álló országok egyaránt üdvözölték a kezdeményezést. A mongol kormány 1997-ben az ENSZ Leszerelési Bizottsága elé terjesztette a tervezetet, és a közgyülés 1998. december 4-én deklarálta, hogy az összes tagállam támogatja a mongol nyilatkozatot (Tuya, 2012, 4.).

Két évvel később, 2000. február 3-án a mongol parlament elfogadta a törvényt, mely rögzítette az ország atomfegyvermentes státuszát (Jakab, 2013, 73.). Ezt követỏen ennek nemzetközi szinten történő intézményesítése vált a legfontosabb céllá, hiszen ez jelenthette Mongólia szuverenitásának politikai és jogi biztosítékát.

A 2000-es évek elején a két szomszédos atomhatalom felvetette, hogy más, Mongóliával nem közvetlenül szomszédos, de atomfegyverrel rendelkező országok is csatlakozzanak a státusz ratifikálásához (Tuya, 2012, 4-6.). Ez végül az első ENSZ-beadvány után húsz évvel, 2012. szeptember 17-én történt meg, amikor Kína, Oroszország, Franciaország, Nagy-Britannia, az USA és Mongólia képviselöi közös nyilatkozatban erösítették meg a 2000-ben már elfogadott kezdeményezést (URL5). Ennek jelentősége csak az utóbbi évek észak-koreai atomfegyver-kísérleteinek fényében mérhető fel igazán. Miközben a mongol státusz elismerése jelentősen hozzájárul a térség biztonságának erősítéséhez, addig Észak-Korea lépései jelentősen gyengítik azt (Damdinsuren, 2008). A Kim-rezsim által generált konfliktus azonban közvetett módon újabb esélyt adott Mongóliának arra, hogy tovább erősítse szerepét a nemzetközi diplomáciában.

\section{SZEREPVÁLLALÁS AZ ÉSZAK-KOREAI KONFLIKTUS(OK)BAN}

Az észak-koreai kérdés megoldásában való mongol szerepvállalásnak nemcsak történeti, de aktuálpolitikai okai is vannak. A történeti távlatot a 2018-ban immár hetvenéves diplomáciai kapcsolat alapozza meg. Mongólia 1948-ban, a Szovjetunió után a világon másodikként ismerte el a Koreai Népi Demokratikus Köztársaságot, s a koreai háború alatt jelentős élelmiszersegélyekkel támogatta az északiakat (URL6). Kim Ir Szen (Kim Il-sung) 1956-ban látogatott elöször Mongóliába, majd harminc évvel később, 1986-ban írták alá a két ország közötti barátsági és együttmüködési szerződést (Panda, 2013). A koreai háború lezárása után szorosak maradtak a gazdasági kapcsolatok, melyek megtorpanását a szovjet szövetségi rendszer felbomlása és a Mongóliában lezajló demokratizálódási folyamat okozta.

Az aktuálpolitikai vonatkozású tényező az, hogy az észak-koreai rezsim által generált konfliktus a rendszerváltás utáni Mongólia két igen jelentős diplomáciai és gazdasági partnerét is közvetlenül érinti. Japán Mongólia egyik legnagyobb támogatója, meghatározó támogatásokat biztosított a mongol gazdaság, infrastruktúra, bankrendszer, az oktatási és egészségügyi rendszer kiépítése és modernizá- 
lása érdekében. Dél-Korea hasonlóan jelentős támogatásokkal, befektetésekkel segíti Mongóliát, ugyanakkor a kivándorló mongol munkaerő egyik legfontosabb célpontja is.

2002-ben Pek Namszun (Paek Nam-sun) észak-koreai külügyminiszter látogatást tett Mongóliában, ami tizennégy év után az első ilyen esemény volt. 2007-ben hasonló szintủ megbeszélésre is sor került, de a fordulópontot Elbegdordzs államelnök 2013. évi phenjani látogatása jelentette, hiszen ő volt az első államfö, aki Kim Dzsongun (Kim Jong-un) hatalomra kerülése után Észak-Koreába utazott.

Mongólia már a 2000-es évek elején felismerte, lehet stratégiai potenciál abban, ha közvetítőként kapcsolódik be az észak-koreai rendezéssel foglalkozó diplomáciai egyeztetésekbe. 2007 szeptemberében és 2012 tavaszán, illetve decemberében Ulánbátor adott helyet a japán és az észak-koreai felek közötti egyeztetéseknek (URL6). Elbegdordzs 2013-as látogatása során már nemcsak a korábbi gazdasági kapcsolatok továbbfejlesztéséről tárgyalt, de a háttérben felmerült annak a lehetősége is, hogy Mongólia mintául szolgálhatna az észak-koreai rendezéshez. A mongol ipar és gazdaság modernizálása, a piacgazdaság kiépítése és integrálása a nemzetközi rendszerbe, a demokratikus átmenet folyamatának lebonyolítása példa lehetne az észak-koreai rendszer átalakítására is.

2014 júniusában a mongol fővárosban rendezték meg az Északkelet-ázsiai Biztonsági Fórumot, ahol elsődleges témaként az Észak-Koreával kapcsolatos gazdasági, biztonságpolitikai és együttmüködési kérdéseket vitatták meg a résztvevők, Oroszország, Kína, Japán, Észak- és Dél-Korea, az USA, Németország, Hollandia és Mongólia képviselői. Ezzel és a következő, 2015. évi magas rangú találkozó segítségével a mongol kormány fontos pozíciókat vívott ki magának a kelet-ázsiai biztonságpolitikai rendezés kérdésében, s ezzel a harmadik szomszéd politika, illetve az aktív kisállami diplomácia célkitűzései megvalósulni látszanak (Bolor, 2016).

2017 azonban némi változást hozott. Kaltma (Khaltmaa) Battulga, az új államelnök győzelmét sokak szerint Kína-ellenes retorikájának köszönhette. Érezhetöek finom elmozdulások a mongol külpolitikai irányokban, melyek az észak-koreai kapcsolatokra is rányomhatják a bélyegüket. Alig fél évvel az államfö beiktatása után már megszavazták a rezsim ellen hozott újabb ENSZ-szankciókat, amihez köze lehet annak, hogy az elmúlt években érezhetően még szorosabbá váltak a mongol-japán kapcsolatok. A japán befektetések mértéke gyarapszik, új beruházásokat hajtanak végre, és csak 2017-ben 850 millió dollárral finanszírozták a mongol gazdaságot. 


\section{ZÁRÓ GONDOLATOK}

Mongólia az elmúlt csaknem három évtizedben sikeresen valósította meg a politikai rendszer átalakítását, és erejéhez mérten külpolitikai elképzeléseit is. A belső-ázsiai posztszovjet térség egyetlen valóban működő demokráciája sikeresen stabilizálta pozícióit a térség geopolitikai struktúrájában. Földrajzi helyzetéből következően nélkülözhetetlen számára a szomszédjaival való jó viszony fenntartása, de célja, hogy a létező gazdasági különbségek ellenére ez a viszony kölcsönösen elönyös legyen. Ebben az egyensúlyozásban Mongólia számára nélkülözhetetlen a gazdaságilag erős kelet- és délkelet-ázsiai országok, s az utóbbi időben egyre nagyobb mértékben India, illetve az USA, az Európai Unió, vagy éppen Törökország gazdasági, politikai támogatása is. Eddigi stratégiája alapjaiban eredményesnek tekinthető, bár az egyre jelentősebb kínai gazdasági befolyást nehezen tudja ellensúlyozni. Nem tudhatjuk, hogy ennek további erösödése milyen politikai következményeket hozhat, a dalai láma 2016. novemberi látogatása által okozott gazdasági problémák azonban nem sok jót vetítenek elöre ebben a kérdésben.

Az ország figyelemre méltó példa lehet nemcsak a közép-ázsiai posztszovjet országok, de bizonyos értelemben a kelet-közép-európai országok számára is. Előbbiek tekintetében abban, hogy miként tudta elkerülni a politikai visszarendeződést, s milyen látványos eredményeket tudott elérni a demokrácia kiépítésének terén; az utóbbiaknak pedig a külpolitikai egyensúlyteremtés kapcsán.

\section{IRODALOM}

Batbayar T. (2002): Mongolia's Foreign Policy in the 1990's: New Identity and New Challenges. Ulaanbaatar: Institute for Strategic Studies

Batchimeg, M. (2005): Future Challenges for the PRC and Mongolia: A Mongolian Perspective. China Brief, 5, 10. https://jamestown.org/program/future-challenges-for-the-prc-and-mongolia-a-mongolian-perspective/

Bolor, L. (2016): Mongolia's Small Country Diplomacy and North Korea. The Diplomat, 19 Sept. 2016. https://thediplomat.com/2016/09/mongolias-small-country-diplomacy-and-northkorea/

Bolor, L. (2017): 30 Years of US-Mongolia Relations. The Diplomat, 2 Febr. 2017. https://thediplomat.com/2017/02/30-years-of-us-mongolia-relations/

Damdinsuren, O. (2008): Institutionalizing Mongolia's Nuclear Weapon Free Zone Status: An Important Contribution to Regional Security. East Asian Security Issues and Regional Cooperation. International Conference, Inha University, https:/www.academia.edu/18677407/ Institutionalizing_Mongolia_s_Nuclear_Weapon_Free_Zone_Status_An_Important_Contribution_to_Regional_Security?auto=download

Ewing, T. E. (1980): Between the Hammer and the Anvil? Chinese and Russian Policies in Outher Mongolia 1911-1921. Bloomington: Indiana University Press 
Gao, C. (2017): After Anti-China Campaign Retoric, Mongolia's President Congratulates China on National Day. The Diplomat, 3 Oct. 2017. https://thediplomat.com/2017/10/after-anti-china-campaign-rhetoric-mongolias-president-congratulates-china-on-national-day/

Jakab L. (2013): Óriások árnyékában. Non-proliferáció mongol módra. Hadtudományi Szemle, 6, 2, http://epa.oszk.hu/02400/02463/00015/pdf/EPA02463_hadtudomanyi_szemle_2013_2_ 068-078.pdf

Panda, A. (2013): What Do North Korea and Mongolia Have in Common? The Diplomat, 30 Oct. 2013. https://thediplomat.com/2013/10/what-do-north-korea-and-mongolia-have-in-common/

Rossabi, M. (2005): Modern Mongolia. From Khans to Comissars to Capitalists. Berkeley: University of California Press

Szilágyi Zs. (2009): Kínai-mongol kapcsolatok a 20-21. század fordulóján. In: Hamar I. - Salát G. (szerk.): Kinai történelem és kultúra. Tanulmányok Ecsedy Ildikó emlékére. Budapest: Balassi Kiadó, 242-256.

Szilágyi Zs. (2010a): Befejeződött rendszerváltás? In: Krausz T. - Mitrovits M. - Zahorán Cs. (szerk.): Rendszerváltás és történelem. Tanulmányok a kelet-európai átalakulásról. Budapest: L'Harmattan, 258-280.

Szilágyi Zs. (2010b): Is the Post-Soviet Tranzition Over? Economic and Social Factors Influencing the Mongolian Democratization Process. In: Csaplár-Degovics K. - Mitrovits M. et al. (eds.): After Twenty Years... Reasons and Consequences of the Transformation in Central and Eastern Europe. Budapest: Terra Recognita Foundation, 109-133.

Szilágyi Zs. (2015): Keleten van-e Mongólia? A mongol demokrácia elmúlt 25 éve. (Mühelytanulmányok 9) Budapest: PPKE BTK Modern Kelet-Ázsia Kutatócsoport, https://btk.ppke.hu/ uploads/articles/447809/file/mkkcsmuhely09_mongolia_demokracia.pdf

Tuya, N. (2012): Mongolia's Nuclear-Weapon-Free Status: Recognition vs. Institutionalization. Massechusetts: The Brooking Institution, https://www.brookings.edu/wp-content/uploads/2016/06/08-nuclear-weapon-free-mongolia-tuya.pdf

URL1: Mongolia-China Relations. http://www.mfa.gov.mn/?p=29545

URL2: International Organization. http://www.imuna.org/resources/country-profiles/mongolia

URL3: Mongolian Peacekeepers Awarded UN Medal In South Sudan. 2017. https://unmiss.unmissions.org/mongolian-peacekeepers-awarded-un-medal-south-sudan

URL4: National Security Concept of Mongolia. http://www.nsc.gov.mn/sites/default/files/images/ National $\% 20$ Security $\% 20$ Concept $\% 20$ of $\% 20$ Mongolia $\% 20$ EN.pdf

URL5: Nuclear-Weapon-Free Status of Mongolia. 2017. http://www.nti.org/learn/treaties-and-regimes/nuclear-weapon-free-status-mongolia/

URL6: Japan's Mongolian Connection in North Korea. 2013. http://www.eastasiaforum. org/2013/11/05/japans-mongolian-connection-in-north-korea/ 